\title{
Collaborative learning within critical mathematics education
}

\section{Bülent Avcı ${ }^{1}$}

\begin{abstract}
Abstrak: Artikel ini menyelidiki bagaimana pembelajaran kolaboratif dalam pendidikan matematika kritis dapat mendorong terwujudnya demokrasi dan sikap warga negara yang kritis untuk melawan hegemoni neo-liberal dalam pendidikan. Merujuk pada penelitian tindakan kelas berbasis partisipasi kritis di kelas sekolah menengah atas di Amerika Serikat, artikel ini menunjukkan bahwa pembelajaran kolaboratif dalam pendidikan matematika kritis merupakan alternatif yang koheren terhadap pendekatan neo-liberal dalam pembelajaran kolaboratif untuk mendorong partisipasi demokratis berbasis keadilan.
\end{abstract}

Kata kunci: Pendidikan matematika kritis, Pembelajaran kolaboratif, Pedagogi neo-liberal, Kewarganegaraan, Demokrasi

\begin{abstract}
This article investigates ways in which collaborative learning in critical mathematics education can promote critical citizenship and democracy to counter neoliberal hegemony in education. Drawing on critical participatory action research in a U.S. high school classroom, the article argues that collaborative learning in critical mathematics education is a coherent alternative to neoliberal approaches to collaborative learning to promote justice based participatory democracy.
\end{abstract}

Keywords: Critical mathematics education, Collaborative learning, Neoliberal pedagogy, Citizenship, Democracy

\section{A. Introduction}

Collaborative learning is a pedagogy that sets regulative norms through which students study and learn together. Collaborative learning in a classroom context can take different forms and be oriented toward different educational goals. In historical context, collaborative learning emerged as a critique of traditional approaches, but it later diffused into mainstream pedagogy and curriculum and lost its original orientation. Today it is often practiced in mathematics classrooms, where it is regarded as a necessary component of effective pedagogical strategies.

The current rationale for collaborative learning is that research has found that it increases students' learning. For example, drawing on classroom-based research, Pietsch (2009) concluded that collaborative learning is an essential part of effective mathematics teaching. Goos (2004) argued that collaborative learning makes learning more meaningful-less a matter of rote memorization - and, moreover, produces cultural forms of learning. Carpenter and Lehrer (1999) suggested that collaborative learning creates a learning environment where

\footnotetext{
${ }^{1}$ Federal Way Public Schools, Washington, the U.S.A, bavci@fwps.org
} 
collective-public reflection can emerge. Franke, Kazemi, and Battey (2007) asserted that collaborative learning creates a discursive ambiance that helps students learn mathematics better. In their comprehensive research studies, Johnson and Johnson (2016) considered collaborative learning in relation to citizenship and democracy.

In theory, collaborative learning seems to have the potential to help students develop values and skills to become critical and engaged citizens. Here it is necessary to frame collaborative learning in a way that cultivates a "thick" version of citizenship and democracy, as described by Wright (2015): that is, as justice-based, participatory democracy. A citizen in this view is one who is committed to equality and freedom; who possesses a sense of collectivity, solidarity, and empathy; who is actively involved in the decision-making process and can question authorities and hold them accountable; who can come together with other citizens to take civil initiatives based on common interests and concerns. Such a citizen is the opposite of the "neoliberal" citizen who is law-abiding and individually responsible, but who practices a form of citizenship ultimately rooted in consumerism.

Critical mathematics education (CME) can be seen as a subset of critical pedagogy. It is a relatively new but growing domain of research concerned with social, cultural, and political implications of mathematics education (Avc1, 2017, 2018; Gutstein, 2006; Skovsmose, 1994, 2011; Skovsmose \& Greer, 2012). Theoretical studies in CME claim that mathematics education can be oriented toward critical citizenship and democracy (Skovsmose, 2011). Thus construction of CME as research field requires defining basic educational concepts such as collaborative learning so that they are aligned with the central concerns of CME.

As a mathematics teacher and researcher, the question of how collaborative learning in CME can be distinguished from its mainstream, neoliberal versions preoccupied me for long time. More specifically, I wanted to understand what the word critical in CME signifies. Unfortunately, there are only a few classroom-based studies that challenge the neoliberal definition of collaborative learning (Avci, 2017). To address this gap, this article draws on classroom-based data to investigate ways in which collaborative learning within CME can counter neoliberal pedagogy and promote critical citizenship and participatory democracy.

\section{B. Methods}

I adopted an action research methodology because it is well suited to the classroom. Resonating with the natural flow of classroom teaching, action research allows the cycle of plan-act-observe-reflect (Carr \& Kemmis, 1986). The methodology enables students to democratically participate in classroom activities and the process of knowledge construction. It can be considered an adaptation of critical participatory action research (CPAR) as framed by Kemmis, McTaggart, and Nixon (2014), in which students are seen as active agents of change as opposed to passive objects of the process: research is done not on students but with them. Therefore, the methodology is conceptually consistent with the concerns of CME.

Action research allows researchers to intervene at different stages. As Herr and Anderson (2005) state, "Unlike traditional social science research that frowns on intervening in any way in the research setting, action research demands some form of intervention" (p. 5). According to Carr and Kemmis (1986), action research is a form of self-reflective enquiry undertaken by participants (teachers, students or principals, for example) in social (including education) situations in order to improve the rationality and justice of (a) their own social or educational 
practice, (b) their understanding of these practices, and (c) the situations (and institutions) in which their practices are carried out (p. 162).

This definition of action research resonates with the objectives of my research. Habermas (1972) argued that knowledge and human interests are strictly correlated, and that the desire for knowledge entails three categories: technical, practical, and emancipatory. Drawing on Habermas's theory of communicative action, Kemmis et al. (2014) relate each interest to a unique epistemological stance and consequently to its own research methodology. Accordingly, types of action research can be categorized as technical, practical, and emancipatory. As Kemmis (2009) points out, these three types "involve very different kinds of constellation of sayings, doings and relating" (p. 469). In CPAR, which is emancipatory, we "find and enact ways of doing things that are less irrational...less unproductive... and less unjust or exclusionary" (Kemmis et al., 2014, p. 68).

I designed the current project as a case study that draws on CPAR's plan-act-observereflect methodology. As I prepared each lesson, through whole-class discussion, I negotiated with my students theme of each lesson. I revised each lesson based on students' reflection. For example, I proposed two themes for one of the CME lessons; one was class-based society and the other race issue. Students decided to go with the first theme: class-based society. Throughout the project, my students worked to achieve egalitarian peer interaction; I facilitated the process. Therefore, this was a participatory action research. Furthermore, the project was a bottom-up respond to top-down imposed neoliberal pedagogy that pictures student as passive receiver of knowledge and teacher as knowledge transmitter. While learning mechanical aspects of mathematics, students had the opportunities to relate their learning to a larger society and system. They seemed developing not only functional literacy, but critical mathematical literacy as well. Thus, this was a critical participatory action research.

The study was conducted in a high school mathematics classroom where I teach fulltime. It involved a year-long, every-day mathematics (pre-calculus) class with 32 students, ages 14 to 17. Data were collected from student journals and whole-class discussions, as well as from my field notes and reflective journal. As Winter (1989) recommended, I analyzed the data from a dialectical perspective, which features three basic premises: (a) although it is a unified whole, a phenomenon is structured in relation with other phenomena; (b) phenomena exist in a context that contains opposite (uncoupling) forces; (c) phenomena are in constant change: change is the result of tension between the unity of the phenomenon and the uncoupling forces.

In order to align the research with these dialectical premises, I used the versus coding method developed by Saldaña (2013). Saldaña's system adequately captures the tensions between collaborative learning in CME and market-driven education. Saldaña (2013) defines the versus coding approach as "identify[ing] in dichotomous or binary terms the individuals, groups, social systems, organizations, phenomena, process, concepts, etc., in direct conflict with each other (p. 115)". Saldaña writes that "versus coding is appropriate for policy studies, evaluation research, critical discourse analysis, and qualitative data sets that suggest strong conflict or competing goals within, among, and between participants (p. 115)". While the initial categories were derived from the research question and conceptual framework, some categories emerged from this preliminary analysis of the data. The a priori and emergent codes informed the categories shown in Table 2. 


\section{Preparation stage of lessons and projects}

As I was developing this project, I realized that there were many factors to consider. For years, the mathematics curriculum in U.S. public high schools has been standardized; indeed, it is admired for being "teacher-proof." Micromanagement policies are in place that tell teachers what, when, and how to teach. On the other hand, because CME is a "subversive" form of teaching, teachers who wish to practice CME must find ways in which it can be situated within the standardized curriculum. Accordingly, I developed projects (lessons) and integrated them into standardized units. In this way-and despite the control that filtered down from district and local administrators-I was able to practice CME during regular school hours.

Collaborative learning should be a process through which students can develop democratic values and attitudes. As Johnson and Johnson (2013) argue, it would be selfdefeating to impose democratic values from the top-down. Instead, collaborative learning should allow students to develop agency by organizing their own groups and making other changes to democratize life in the classroom.

Prior to developing the action research projects, I had some questions and concerns:

- Problems and questions should not be too easy or too difficult. In both cases, students may lose concentration or be discouraged. Students should need mathematical content knowledge to participate in group discussions.

- Projects should help students improve their content knowledge; this is necessary to counter a widespread bias against critical pedagogy that critical pedagogy (and CME) is inconsistent with rigorous learning.

- Peer interaction in small groups should be nondominating and dialogic. However, this runs counter to the U.S. school system, where learning is structured as competitive. How to challenge this fundamental belief? Should we have whole-class discussions to discuss the pros and cons of collaborative vs. competitive learning?

- Should students set their own groups or should I be involved in the process? In the U.S., ethnic pride is often confused with multicultural education. What if students set groups based on ethnicity or race? This would defeat our purpose, as collaborative learning should help students interact with their peers based on universal values, regardless of race or culture.

- As I developed projects, I needed to be aware not to fall into default, neoliberal ways of thinking. For example, word problem themes should not be based on competition or consumerism, but rather should resonate with ethics of emancipation, collectivity, and solidarity; they should also relate to students' own lifeworlds. This can motivate students so that they would not need extrinsic motivational supports.

- Each project needs to be linked to the state standards. As micromanagers, school administrators often visit classrooms to ensure teachers follow the standardized curriculum. I needed to make the grade.

As my students and I became immersed in the first project, my students and I gradually began to find answers to these questions. In cycles of plan-act-observe-reflect, some questions evolved into others, and new concerns emerged along the way. 


\section{Participatory action research in the mathematics classroom}

The study included five projects, one per month. Two were mechanical exercises; the others were open-ended word problems. The projects shown in Table 1 were the main source of data.

Table 1. Content and themes of End-of-Unit Projects (EUPs)

\begin{tabular}{cll}
\hline EUP & \multicolumn{1}{c}{ Mathematics content } & \multicolumn{1}{c}{ Theme } \\
\hline 1 & Linear equations and functions & $\begin{array}{l}\text { Standardized (multiple-choice) } \\
\text { assessment } \\
\text { Critical mathematical literacy: class } \\
\text { consciousness }\end{array}$ \\
2 & $\begin{array}{l}\text { Multipart functions: graphical and } \\
\text { algebraic analysis of domain and } \\
\text { range }\end{array}$ & $\begin{array}{l}\text { Collaboration versus competition } \\
\text { Community service: charity versus } \\
\text { solidarity }\end{array}$ \\
4 & $\begin{array}{l}\text { History of mathematics } \\
\text { Systems of equations and inequalities }\end{array}$ & $\begin{array}{l}\text { Exponential equations, functions and loan debt crisis } \\
\text { models }\end{array}$ \\
\hline
\end{tabular}

Each project required two lessons. We began each with a whole-class discussion concerning objectives. One of our goals was to achieve egalitarian peer interaction and collaborative learning in small-group work. I then introduced the project; this was followed by group work and group presentations. Then we had another class discussion to reflect on our practices. At the end of the project, students made entries in their journals. I took field notes and wrote in my reflective journal. Before next project, I discussed potential themes of next lesson with my students and revised the lesson accordingly.

\section{Findings and Discussion}

I completed data collection and analysis simultaneously for each project; analysis of each project affected the subsequent project. For example, as I facilitated the first project (EUP 1), I analyzed data to prepare the next project (EUP 2). And at the end of the study, taken together, I carried out the final analysis of the project.

This section includes key findings of the study and related discussions.

\section{Setting up the groups}

Setting up groups for collaborative learning may seem to be an insignificant detail; however, my research revealed that group-setting is a crucial step, as it directly relates to the goals of collaborative pedagogy. Without having any discussion of group-setting, I let students set their own groups for the first two projects. My intention was to observe students' natural inclination toward group work. For these projects, students seemed to come together mostly based on cultural and ethnic background. Eduardo voiced this sentiment in his journal:

It was easy for me to say, "Hey, James, let's do this [project] together." They are my

friends anyway, but I am not sure what the other dude would say about it.

This quotation is from the first project, which indicates that the class was not yet a community: students chose their friends, not ready yet to work together regardless of background. As the teacher, I noticed that there is a dialectic relation between the classroom being a community and successful application of collaborative learning. Collaborative 
learning is something that has to be learned through systematic work. Ethnic loyalty seemed to be an obstacle to transforming the class into a community.

Organizing groups as multicultural and cross-gender was challenging at first. However, as we went further, students seemed to be interacting, studying, and learning better in group work. During the third and fourth projects, we discussed setting up groups, and agreed that we should be able to work with all classmates, regardless of ethnic, racial, or any other identity - this is our classroom, our community. In the fifth project, students set their own groups again. But this time, it was noticeable that the groups were, by any measure, much more mixed.

In a larger context, students' tendency to feel comfortable with others from their own background was not a coincidence. It is an observable fact that the power elite in the U.S. uses racial, ethnic, religious, and cultural differences to keep people from coming together to organize themselves around their common interests and problems to take collective initiatives in the public arena. Therefore, a practice of CME aimed at promoting critical citizenship should encourage students to develop civic skills to work collaboratively with their peers from diverse backgrounds.

After reflecting on previous experience with group work, some students proposed that assigning each member a specific task would improve the quality of work. This was another important question: should the teacher assign each member of a group a specific task? We had several whole-class discussions on this issue, and agreed that assigning each student a task defeats the purpose of collaborative learning, which is to help students develop skills, attitudes, and values to become engaged and critical citizens. Whereas collaborative learning should give students autonomy and help them grow as independent learners, assigning specific tasks would be controlling and micromanaging. Similarly, when people (citizens, workers, activists, etc.) organize grassroots movements, it is usually a matter of civil initiative. No one is officially (top-down) assigned a specific task - citizens define problems, develop plans, and mobilize themselves. They may perhaps decide on some division of labor, but that is a joint decision, not an imposed one.

It is interesting to reflect that small-group collaboration in which each member is assigned a specific task is, however, functional from a business perspective: employers seek workers who can work with others to carry out specific tasks assigned by the manager. But such pedagogy would be far from helping students develop a sense of solidarity, collectivity, and empathy. Instead, top-down tasks would appear to promote individually responsible, consumer-based citizenship. Indeed, if a person completes their part of the work without having any say in the overall problem, then this process may produce alienated individuals who do as they are told to earn a wage (in the business context) or a credit (in the educational context). This situation is not collaboration but compliance.

Therefore, collaborative learning in CME should empower students to set groups with peers not necessarily from their ethnic group, to determine division of labor, and to complete group work democratically. Working toward egalitarian collaboration in the classroom is not to deny that individual students have different talents and skills. Through the five projects, there was no evidence that a student considered their peers to be obstacles to success. We established a synergistic relationship between individual students and groups such that individual growth led to growth of the whole classroom community and vice versa. 


\section{Motivation for learning: Extrinsic vs. Intrinsic}

Students were asked to reflect on their group-work experiences in the past. Lauren articulated her frustration: "This is what happens. One or two do all the work and everyone else in the group gets credit from that work without doing their fair share." This is a legitimate concern when leaning is structured within a reward/punishment paradigm. Students' journals also indicated that when assignments do not relate to their own lifeworld, some complete the project just for the credit, while others do not even bother with the credit.

From the perspective of market-driven education, Farrell and Lawrence (2016) consider the kind of collaboration we practiced as counter-productive to the purpose of career readiness. Their position is a reminder that pedagogical practices involving cooperation and collaboration are never neutral, but have contentious ideological and political implications. Market-driven education - which aims to promote consumer-based, individually responsible citizenship - promotes collaborative learning in school because it envisions students as future workers who are going to need skills to work with others to solve problems assigned by managers.

At the start of each project, we also debated whether it should be graded. It was decided that learning is its own reward: we did not need academic credit for every activity undertaken in class. Therefore, the projects were not graded in the traditional sense. However, I took special care to ensure that the projects were related to students' lifeworlds. Thus the motivation was intrinsic, not extrinsic. Many students, like Jennifer, expressed their opinion in their journals:

I don't care if it was graded or not, the fishing-town project was a really enjoyable one.

It made me feel like we were working on something real... It was not like doing couple of math exercises.

As Jennifer indicates, it is important that themes of projects in CME should be derived from students' lifeworld - something they find interesting. In this way, collaborative learning in small groups was engaging and meaningful for students.

\section{Power dynamics in peer interaction (ZPD)}

Vygotsky's (1978) notion of the zone of proximal development (ZPD) was one of my inspirations toward collaborative learning in the first place. According to ZPD theory, students' intellectual performance differs drastically when performing alone compared to when performing with the assistance of the teacher or a more competent classmate. However, surprisingly, my experience led to the conclusion that ZPD in the context of peer tutoring may produce power relations among students, generating what Freire (2000) referred to as the "banking" concept of education. When the objective is to foster a culture of collectivity and solidarity, peer tutoring must not be allowed to become another version of transmissionstyle education. If students cannot interact with each other as equals, then the classroom is not an egalitarian community. ZPD might help students learn mathematics better and improve their functional literacy; however, from the perspective of $\mathrm{CME}$, it has the potential to be a dehumanizing and oppressive learning experience.

Students also identified self-assigned leaders as obstacles to egalitarian work. The power of self-appointed leaders can come from a variety of sources. I noticed that if students can bring their status with them into the classroom, peer interactions tend to reproduce power relations and hierarchy. Then one student dominates the other members of the group. During 
the first two projects, I observed a particular student, a popular football player, who was dominating the group: the other members seemed to be passive followers; their voices went unheard. In a different group, a student whose parents were lawyers (high status in a lowincome school) interacted with her group in a way that clearly indicated that the group was supposed to follow her direction.

Before and after each project, we discussed ways to achieve egalitarian collaboration. Students' reflections indicated that they actually enjoyed interacting with each other as equal members. As we completed more projects, students began approaching one another with empathy. Denny's journal entry for the fifth project captures this sentiment:

I always thought I knew the answer... I figured it out before anyone else, but when we talked with each other, it was much more than what I thought... There were many different ways to calculate how much the oil company should pay fishing families2. ...I realized how important it is to listen to your friends and see their thoughts and feelings.

Thus, as time went on, egalitarian collaboration gradually emerged. Students made a conscious effort to establish empathetic and nondominating interactions with their peers. It would be very difficult, if not impossible, to create a learning environment where students can learn with and from each other if power relations or hierarchies of any kind play defining roles in interactions. Pedagogy oriented toward collaborative learning to promote participatory and justice-based critical citizenship requires that the classroom is an egalitarian community where students' interactions are guided by empathy and solidarity.

\section{Learning materials}

Five cycles of planning, teaching, observing, and reflecting on collaborative learning led to the conclusion that learning materials and projects must be conducive to collaboration. Three of five projects involved open-ended word problems that provided communicative space for students to link their learning to the larger world outside the classroom. In these problems, there was no single correct answer; these were inquiry-based, multilayered questions that allowed students to negotiate different approaches. The following quote is from one of the small-group projects where students worked on the real-world problem that deals with optimization:

\begin{tabular}{|c|c|}
\hline Nadia & If we maximise something, don't we need a quadratic function? \\
\hline Nicole & $\begin{array}{l}\text { I think so...but some linear inequalities can be optimised. You know, } \\
\text { just like we did in exercises last week from the textbook.... }\end{array}$ \\
\hline Nadia & We need to maximise a function, but what function? \\
\hline Nicole & $\begin{array}{l}\text { Yeah...that is what we need to figure out.... We need to write that } \\
\text { equation down first.... Here we need to add family and individual unit } \\
\text { prices [she wrote inequalities down]. }\end{array}$ \\
\hline Tom & $\begin{array}{l}\text { Why did we set inequalities in standard form and put into slope- } \\
\text { intercept later? }\end{array}$ \\
\hline Nicole & It is easier to graph it in slope-intercept form. \\
\hline Tom & Then we should have set it in slope form in first place. \\
\hline
\end{tabular}

\footnotetext{
2 "Fishing Town" was one of our projects: a big oil company polluted the ocean, and citizens sued the corporation for compensation.
} 
Nicole : I don't know how to set it. It comes easy to set it in standard form when I read the problem.... [They wrote all inequalities and the objective function down].

Tom : I wonder if Edward ${ }^{3}$ gets money for this work.

Nadia : Maybe some pocket money.... Why not?

Nicole : He is doing a community service here; he has a part-time job...you know, in the other project he got a part-time job.

Once students agreed that the system of inequality corresponds to Edward's story and the objective function, they moved on to calculations and graphing:

Nadia : Looks like our solution area has three edge points...x-intercept is 20 and $y$ is 15 .

Nicole : I got the same, but let's plug them in and see how they work...II also got the intercept of two lines.

Tom : Yes, $x$ and $y$ intercepts are correct.

Nadia : Let's evaluate objective function....Tom, can you do it by calculator?

Tom : Yes, $P(x, y)$ is the objective function right? [Pointing to their objective function]

Nicole : Oh yeah, that's the equation [she pointed to the equation] .... This is going to calculate the total money they could get.

This quotation reveals that each member of the group contributed to the process of collective thinking. Even though their skills and knowledge vary, they learned from and with each other.

The other two projects involved practice sessions on mechanical exercises. Mathematics contains properties, axioms, and theories, etc. Comparing skill-drill exercises to open-ended word problems, the exercises seemed to not provide a lively communicative space. Students working on exercises in groups appeared to be less motivated and more likely to digress. This outcome is supported by Skovsmose (2014), in his article landscape of investigation, who writes that $\mathrm{CME}$ should be critical of official curriculum-he conceptualizes it as exercise paradigm and create a landscape of investigation for students to be engaged in meaningful learning process; the landscape of investigation in my research formed a communicative space that provided a solid ground for dialogical pedagogy and collaborative learning.

In this context, I openly communicated the following point with them: in today's market-driven education system, where success of schools, teachers, and students is measured by standardized test results, it is important for students to have functional literacy and be able to pass the tests. That is to say, students need skill-drill type of mathematical knowledge to be successful in a traditional sense. However, this doesn't mean that teaching mechanical exercises in mathematics is a neutral process where the pedagogic approach makes no difference. For teaching the mechanical aspects of mathematics, CME should make a distinction between authoritarian and dialogic pedagogy: mathematics can be taught and learned through dialogic pedagogy. Anything that can be taught through the authoritarian

\footnotetext{
${ }^{3}$ Edward is the character in the word-problem who volunteers in a community service.
} 
approach can also be taught through dialogic pedagogy. Of course, CME strongly prefers dialogic pedagogy as it cultivates democratic values and attitudes.

\section{Classroom life: Democracy vs. Compliance}

Throughout five projects, as we worked to achieve egalitarian collaboration, our classroom became a community of learners. In this process, I, as the teacher, became a facilitator. Students' interactions with each other became less dominating and more empathetic; classroom life became more democratic. Such effects demonstrated that our discussions of justice-based participatory democracy and critical citizenship were not empty rhetoric. The more that collaborative learning democratized the class, the more participatory became our discussions on ways to transform the class into a community. For example, by the time we (my students and I) completed the third project, the following list of norms had been agreed on:

- In group work, we will approach each other empathetically, not judgmentally. We have a common goal to achieve.

- We continuously are working to establish nondominating interactions. Regardless of where we come from, we are all equal in this class; we have an equal right of saying things and doing things in group work.

- We actively participate in discussions in our groups and in the class. We focus on individuals' arguments, not on their power or personality.

- If for some reason a member is shy and unwilling to participate, group friends welcome and encourage them.

- We can disagree on things; that is normal. However, it is important that we democratically solve these disagreements without excluding anyone. A group member may have a different way of solving problems or answering questions. We solve issues through open dialogue and egalitarian peer interaction.

- Nothing should be imposed on group members: groups decide how to plan, carry out, and present the project.

Agreeing to these regulative norms meant that students made a public commitment to them. Students developed a noticeable sense of belonging as individuals contributed to group work and found that their ideas and work were valued. Unlike the situation that exists in competitive learning, our collaborative activities did not create winners and losers. Quite the contrary: collaborative learning processes dialectically connected individual students' success to the success of whole class. As such, the collaborative learning process was an important element in transforming the class into an egalitarian community of learners.

With respect to the connection between democracy and mathematics education, Dewey (1916) claimed that scientific education, including mathematics, lead naturally to a democratic society, because science and mathematics reject external authority of any kind. My research, however, led to a different conclusion: how mathematics is taught is equally, if not more, important than the content itself. If mathematics is taught in an authoritarian way, it will promote authoritarian, not democratic, values. I agree with Skovsmose and Alrø (2004), who suggested that in this respect, CME needs to transcend the views of Dewey. 
Taken together, collaborative learning in CME may be distinguished from neoliberal (mainstream) pedagogy. As Table 2 indicates, CME and neoliberal pedagogy differ across five key domains.

Table 2. Key differences between CME and Neoliberal Pedagogy

\begin{tabular}{|c|c|c|}
\hline Domain & $\begin{array}{l}\text { Critical Mathematics } \\
\text { Education (CME) }\end{array}$ & Neoliberal Pedagogy \\
\hline 1 Setting up the groups & $\begin{array}{l}\text { Students set and self- } \\
\text { organize their own group in } \\
\text { an egalitarian manner; } \\
\text { sense of community and } \\
\text { horizontal relationships }\end{array}$ & $\begin{array}{l}\text { Teacher assigns each student } \\
\text { to a specific task or } \\
\text { responsibility; } \\
\text { negligible sense of } \\
\text { community }\end{array}$ \\
\hline $\begin{array}{l}2 \text { Motivation for learning: } \\
\text { extrinsic vs. intrinsic }\end{array}$ & $\begin{array}{l}\text { Intrinsic; subject matter } \\
\text { relates to students' lifeworld } \\
\text { (e.g., pollution) }\end{array}$ & $\begin{array}{l}\text { Extrinsic (test scores, grades); } \\
\text { subject matter typically from } \\
\text { consumer or business world } \\
\text { (e.g., best-buy or profit } \\
\text { maximization option) }\end{array}$ \\
\hline $\begin{array}{l}3 \text { Power dynamics in peer } \\
\text { interaction (ZPD) }\end{array}$ & Interactions of equals & $\begin{array}{l}\text { Replication of existing } \\
\text { dynamic: teacher is authority; } \\
\text { peer tutoring may lead to } \\
\text { emergence of banking model }\end{array}$ \\
\hline 4 Learning materials & $\begin{array}{l}\text { Open-ended word problems } \\
\text { afford links to larger world } \\
\text { and multilayered responses }\end{array}$ & $\begin{array}{l}\text { Skill-drill exercises limit } \\
\text { opportunities for empathy and } \\
\text { collaboration }\end{array}$ \\
\hline $\begin{array}{l}5 \text { Classroom life: democracy } \\
\text { vs. compliance }\end{array}$ & $\begin{array}{l}\text { Justice-based participatory } \\
\text { democracy; } \\
\text { "thick" version of } \\
\text { democracy and citizenship }\end{array}$ & $\begin{array}{l}\text { Collective compliance; } \\
\text { individually responsible } \\
\text { students carry out specific } \\
\text { tasks; "thin" version of } \\
\text { democracy and citizenship }\end{array}$ \\
\hline
\end{tabular}

\section{Conclusion}

This study as a classroom-based research made a number of contributions to existing CME literature. First, it showed that high school mathematics students can interact with one another in nondominating, dialogic, and empathetic ways: achieving egalitarian peer interaction is difficult, but attainable. Second, the study indicated that collaborative learning in the context of CME could be structured as a process through which students experience learning with and from each other and become agencies of change to democratize life in classroom. Third, the study, however, also showed that collaborative learning is a sustainable practice when it gradually transforms the class into an egalitarian community of learners. That is to say, collaborative learning should be organized to transform classroom to a community of learners. And then, collaborative learning may promote values and skills that students need to become active and critical citizens instead of producing or reproducing existing power relations. Thus collaborative learning in CME is sharply distinguished from collaborative learning in mainstream educational practices.

\footnotetext{
${ }^{4}$ Zone of Proximal Development (ZDP)
} 
I hope it is apparent from the foregoing that this was (critical) participatory action research in which students were, to a large degree, active participants and co-researchers. Loren's final journal entry sums up her thoughts and feelings:

To be honest, I am not a math person....Math was never my strength. I always felt anxious as I stepped into my math classes,...but this year was quite different. I mean like really different.... We were all talking together in class to improve our group work, make our class an equal place....I was included in all projects we did. Everybody asked questions of each other and we talked about a lot of social issues and learned a lot....In the fishing-town project,...I actually learned how to find intercept points of lines and circles with and without a calculator...I will miss this class.

While this study provides a frame indicating the ways in which collaborative learning in CME can counter neoliberal pedagogy, more classroom-based critical participatory researches in secondary math classrooms in different settings are needed to improve this frame.

\section{References}

Avc1, B. (2017). Critical mathematics education in neoliberal era. (PhD dissertation, Charles Sturt University). Retrieved from https://researchoutput.csu.edu.au/en/publications/criticalmathematics-education-in-neoliberal-era

Avc1, B. (2018). Critical mathematics education: Can democratic mathematics education survive under neoliberal regime? Boston, MA: Brill-Sense.

Carpenter, T. P., \& Lehrer, R. (1999). Teaching and learning mathematics with understanding. In E. Fennema \& T. A. Romberg (Eds.), Mathematics classrooms that promote understanding (pp. 1932). Mahwah, NJ: Erlbaum.

Carr, W., \& Kemmis, S. (1986). Becoming critical: Education, knowledge, and action research. London: Falmer Press.

Dewey, J. (1916). Democracy and education: An introduction to the philosophy of education. New York: Free Press.

Farrell, J. P., \& Lawrence, G. (2016). Rotten to the (Common) Core: Public Schooling, Standardized Tests, and the Surveillance State. Port Townsend, Washington, USA: Process.

Franke, M. L., Kazemi, E., \& Battey, D. (2007). Understanding teaching and classroom practice in mathematics. In F. K. Lester (Ed.), Second handbook of research on mathemaics teaching and learning (pp. 225-256). Greenwhich, CT: Information Age Publishers.

Freire, P. (2000). Pedagogy of the oppressed. New York: Continuum.

Goos, M. (2004). Learning mathematics in a classroom community of inquiry. Journal for Research in Mathematics Education, 35(4), 258-291. Doi: 10.2307/30034810

Gutstein, E. (2006). Reading and writing the world with mathematics: Toward a pedagogy for social justice. New York: Routledge.

Habermas, J. (1972). Knowledge and human interests. Boston: Beacon.

Herr, K., \& Anderson, G. L. (2005). The action research dissertation: A guide for students and faculty. London: Sage.

Johnson, D. W., \& Johnson, F. P. (2013). Joining together: Group theory and research. Boston: Allyn $\&$ Bacon.

Johnson, D. W., \& Johnson, R. (2016). Cooperative learning and teaching citizenship in democracies. International Journal of Educational Research, 76, 162-177. Doi: 10.1016/j.ijer.2015.11.009

Kemmis, S. (2009). Action research as a practice-based practice. Educational Action Research, 17(3), 463-474. Doi: 10.1080/09650790903093284

Kemmis, S., McTaggart, R., \& Nixon, R. (2014). The action research planner. New York: Springer. 
Pietsch, J. (2009). Teaching and learning mathematics together: Bringing collaboration to the centre of the mathematics classroom. Newcastle upon Tyne, UK: Cambridge Scholars Publishing.

Saldaña, J. (2013). The coding manual for qualitative researchers. Los Angeles: Sage.

Skovsmose, O. (1994). Towards a philosophy of critical mathematics education. London: Kluwer Academic Publishers.

Skovsmose, O. (2011). An invitation to critical mathematics education. Retrieved from http://WISC.eblib.com/patron/FullRecord.aspx?p=974110

Skovsmose, O., \& Alrø, H. (2004). Dialogue and learning in mathematics education: Intention, reflection, critique (Vol. 29). New York: Springer.

Skovsmose, O. (2014). Landscapes of investigation. In B. Sriraman (Ed.), Critique as uncertainty (pp. 3-20). Charlotte, NC: Information Age Publishing.

Skovsmose, O., \& Greer, B. (2012). Opening the cage: Critique and politics of mathematics education. Rotterdam: Sense Publishers.

Vygotsky, L. S. (1978). Mind in society: The development of higher psychological processes. Cambridge, MA: Harvard University Press.

Winter, R. (1989). Learning from experience: Principles and practice in action-research. London: Falmer.

Wright, D. E. (2015). Active learning: Social justice education and participatory action research. New York: Routledge 